\title{
JUMLAH HEMOSIT TOTAL PADA UDANG VANAME (Litopenaeus vannamei) YANG DIBERIKAN TAMBAHAN TEPUNG BATANG PISANG PADA PAKAN
}

\section{TOTAL HEMOSITES IN SHRIMP VANAME (Litopenaeus vannamei) PROVIDED BY ADDITIONAL BANANA FLOUR IN FEED}

\author{
Adni Oktaviana $^{1 *)}$, Dian Febriani ${ }^{1)}$ \\ ${ }^{1)}$ Program Studi Budidaya Perairan, Politeknik Negeri Lampung
}

\begin{abstract}
Abstrak
Penelitian ini bertujuan untuk mengetahui jumlah hemosittotal dan sintasan udang vaname (L. vannamei) yang diberikan pakan dengan penambahan tepung batang pisang. Penelitian ini terdiri dari tiga perlakuan dengan tiga ulangan. Rancangan percobaan yang digunakan adalah rancangan acak lengkap (RAL) pada taraf kesalahan 5\%. Perlakuan yang dilakukan adalah pemeliharaan udang vaname dengan pemberian pakan yang diberikan penambahan tepung batang pisang dengan dosis $0 \mathrm{gr} / \mathrm{kg}$ pakan (A), pemeliharaan udang vaname dengan pemberian pakan yang diberikan penambahan tepung batang pisang dengan dosis $4 \mathrm{gr} / \mathrm{kg}$ pakan (B) dan pemeliharaan udang vaname dengan pemberian pakan yang diberikan penambahan tepung batang pisang dengan dosis $6 \mathrm{gr} / \mathrm{kg}$ pakan $(\mathrm{C})$. Parameter yang diamati adalah sintasan (SR), jumlah hemosit total (THC) dan pengukuran kualitas air. Parameter kualitas air yang diukurterdiridarisuhu, oksigenterlarut (DO), nilai pH, dankan dungan amoniak. Nilai SR yang diperoleh pada penelitian ini berturut-turut yaitu B $(91,30 \%)$, C $(88,40 \%)$ dan A $(81,15 \%)$.
\end{abstract}

Kata kunci: udangvaname, total hemosit, sintasan, tepung batang pisang

\begin{abstract}
This study aims to determine the total number of hemocytes and the survival of vaname shrimp (L. vannamei) which are fed with the addition of banana stem flour. This study consisted of three treatments with three replications. The experimental design used was a completely randomized design (CRD) at an error level of 5\%. The treatments taken are the maintenance of vaname shrimp by feeding them with the addition of banana stem flour with a dose of $0 \mathrm{gr} / \mathrm{kg}$ of feed (A), maintenance of vaname shrimp by feeding them which is given the addition of banana stem flour with a dose of $4 \mathrm{gr} / \mathrm{kg}$ of feed (B) and maintenance of vaname shrimp by feeding them with the addition of banana stem flour at a dose of $6 \mathrm{gr} / \mathrm{kg}$ of feed (C). The parameters observed were survival rate (SR), total hemocyte count (THC) and water quality measurements. Water quality parameters measured consisted of temperature, dissolved oxygen (DO), $\mathrm{pH}$ value, and ammonia content. SR values obtained in this study were B $(91.30 \%), \mathrm{C}(88.40 \%)$ and A $(81.15 \%)$, respectively.
\end{abstract}

Keywords: total hemocytes count, pasicif white shirmp, survival rate, banana stem flours

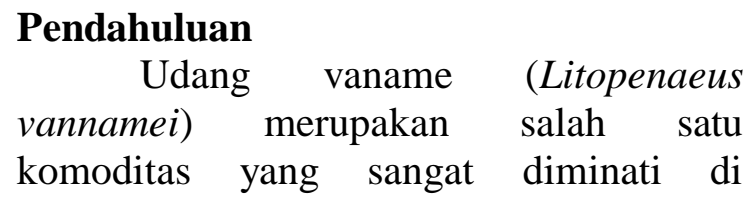

*) korespondensi : adni_zein@polinela.ac.id masyarakat. Menurut data Shrimp Club Indonesia $(\mathrm{SCI})$ produksi udang Indonesia padatahun 2016 hanya sekitar 265.000 ton, menurun dari tahun 2014 sebesar 300.000 
ton (Zulfa, 2018). Hal tersebut mempengaruhi produksi udang vaname di pasaran sehingga memberikan dampak yang signifikan terhadap produksi udang nasional (Medistiara, 2017). Salah satu yang menyebabkan penurunan produksi udang vaname adalah serangan penyakit. Menurut Utami, dkk (2016), usaha pengembangan budidaya udang vaname tidak dapat terlepas dari serangan penyakit. Oleh karena itu, diperlukan alternative untuk meningkatkan produksi udang vaname dengan cara meningkatkan kesehatan udang vaname. Salah satu cara untuk meningkatkan kesehatan yaitu dengan penambahan ekstrak batang pisang. Beberapa penelitian telah melaporkan khasiat penambahan ekstrak batang pisang terhadap peningkatan kesehatan ikan gurame, lele dan udang vaname (Efrianti, 2013; Lidiawati, 2014; Indraswari, 2016dan Ramadhan, dkk, 2017)

Batang pisang merupakan limbah pertanian potensial yang belum banyak dimanfaatkan. Munadjim (1983), menyatakan bahwa sebanyak $60 \%$ dari total produksi tanaman pisang terletak pada batang pisang. Berdasarkan data rata-rata produksi pisang selama tahun 2011-2015 Provinsi Lampung menempati urutan ketiga sebagai provinsi sentra produksi pisang. Dimana Provinsi Lampung memberikan kontribusi terhadap produksi pisang nasional sebesar 18,20\%. Dengan total produksi pada tahun 2015 sebesar 1.937.348 ton (Pusat Data dan Sistem Informasi Pertanian, 2016). Batang pisang terdapat kandungan gizi seperti karbohidrat (66\%), protein, air, mineral dan pati (45 $\%$ ) (Kartika dan Suryaningtyas, 2015). Serta mengandung beberapa senyawa aktif seperti tannin, saponin dan flavonoid (Priosoeryanto, dkk, 2006). Senyawasenyawa tersebut berpotensi sebagai antibakteri dan imunostimulan. Penambahan ekstrak batang pisang dengan metode maserasi dengan dosis pemberian $0,5 \mathrm{~g} / \mathrm{kg}$ pakan dapat meningkatkan sistem kekebalan tubuh non spesifik udang putih terhadap penyakit bintik putih (Ramadhan, dkk, 2017). Pemberian tepung batang pisang pada pakan udang vaname belum dilaporkan sehingga penelitian ini perlu dilakukan dan diharapkan dapat meningkatkan kesehatan udang vaname.

Salah satu faktor penentu keberhasilan budidaya adalah kesehatan organisme yang dibudidaya. Budidaya udang yang semakin menurun tiap tahun karena terkendala rendahnya pertumbuhan dan serangan penyakit. Beberapa cara dilakukan oleh para pembudidaya dalam meningkatkan keberhasilan budidaya udang. Salah satu cara yang dapat dilakukan adalah dengan penambahan berbagai bahan alami yang dapat memacu kesehatan. Batang pisang telah dilaporkan mengandung senyawa-senyawa yang dapat meningkatkan imunostimulan pada beberapa budidaya ikan air tawar. Penelitian ini bertujuan untuk mengetahui jumlah total hemosit dan sintasan udang vaname (L. vannamei) yang diberikan pakan dengan penambahan tepung batang pisang.

\section{Metode}

\section{Waktu dan Tempat}

Penelitian ini akan dilaksanakan pada bulan Juli-September 2019. Penelitian ini akan berlokasi di Laboratorium Budidaya Perikanan Politeknik Negeri Lampung, Bandar Lampung.

\section{Analisa data}

Rancangan percobaan yang digunakan adalah rancangan acak lengkap (RAL). Penelitian ini terdiri dari tiga perlakuan dengan tiga ulangan, yaitu pemeliharaan udang vaname dengan pemberian pakan yang diberikan penambahan tepung batang pisang dengan dosis $0 \mathrm{gr} / \mathrm{kg}$ pakan (A), pemeliharaan udang vaname dengan pemberian pakan yang diberikan penambahan tepung batang pisang dengan dosis $4 \mathrm{gr} / \mathrm{kg}$ pakan (B), dan pemeliharaan udang vaname dengan pemberian pakan yang diberikan penambahan tepung batang pisang dengan dosis $6 \mathrm{gr} / \mathrm{kg}$ pakan (C). Data yang 
diperoleh akan diuji secara statistic dan diuji lanjut dengan uji beda nyata Duncan dengan kepercayaam 95\%. Data yang akan diuji statistik adalah sintasan, $\mathrm{SR}=$ $(\mathrm{Nt} / \mathrm{N} 0) \times 100$; dan total hemosit, $\mathrm{THC}=$ rata-rata jumlah sel terhitung $\mathrm{x}(1 /$ volume kotak) $\mathrm{x}$ Faktor Pengencer. $\mathrm{Nt}=$ jumlah udang pada awal penelitian; N0 = jumlah udang pada akhir penelitian.

\section{Persiapan HewanUji dan Media Pemeliharaan}

Hewan uji yang digunakan pada penelitian ini adalah benih udang (benur) vaname stadia postlarva (PL) 10, yang berasal dari hatchery komersil di Kalianda, Bandar Lampung. Sebelum digunakan benur dipelihara terlebih dahulu selama kurang lebih 30 hari. Hal ini bertujuan untuk mengadaptasikan benur pada media bersalinitas 15 ppt. Salinitas air laut diturunkan secara perlahan setiap harinya hingga mendapat salinitas 15 ppt. Penurunan salinitas air laut dilakukan dengan menambahkan air tawar 5\% dari volume air laut dalam akuarium. Penambahan air tawar sebanyak $5 \%$ dari volume air laut dalama kuarium bertujuan untuk menurunkan salinitas air laut sebesar 2 ppt. Volume media pemeliharaan sebanyak 45 liter. Wadah yang digunakan berupa akuarium berukuran $50 \mathrm{~cm}$ x $30 \mathrm{~cm}$ $\mathrm{x} 40 \mathrm{~cm}$ sebanyak 9 buah yang telah didesinfeksi. Kemudian akuarium di tutup dengan plastic hitam untuk menghindari stress pada udang dan diberikan aerasi. Padat tebar yang digunakan adalah 0,5 ekor/liter.

\section{PemeliharaanUdangVaname}

Pemeliharaan udang vaname

dilakukan selama 4 minggu. Selama pemeliharaan dilakukan pengontrolandan pengecekan kualitas air. Penyiponan dilakukan setiap 1 minggu sekali yang bertujuan untuk membersihkan sisa pakan dan juga feses udang. Selama pemeliharaan udang diberikan pakan uji dengan frekuensi pemberianpakan(FF) sebanyak3 kali sehari yaitu pada pukul
07.00; 13.00dan 19.00.WIB. Tingkat pemberian pakan (FR) sebesar 5\%. Pakan uji yang digunakan pada penelitian ini berupa pelet dengan kandungan protein sebesar $40 \%$ dan dengan pencampuran tepung batang pisang.

\section{Pembuatan Tepung Batang Pisang}

Bagian yang digunakan adalah batang pisang yang sudah dipotong $25 \mathrm{~cm}$ dari batas bawah pelepah dan $25 \mathrm{~cm}$ dari bongol. Kedua bagian tersebut kemudian dihomogenkan. Pembuatan tepung batang pisang dilakukan dengan mencacah halus batang pisang. Kemudian cacahan batang pisang tersebut jemur selama 3 hari atau sampai kering. Setelah kering cacahan batang pisang tersebut ditumbuk hingga halus lalu disaring dengan menggunakan saringan berukuran $1 \mathrm{~mm}$ (Antonius, 2014).

\section{Persiapan Pakan Uji}

Pakan yang digunakan pada penelitian ini berupa pelet dengan kandungan protein sebesar $40 \%$. Pakan uji dibuat dengan menambahkan tepung batang pisang dengan dosis $0 \mathrm{gr} / \mathrm{kg} ; 4$ $\mathrm{gr} / \mathrm{kg}$ dan $6 \mathrm{gr} / \mathrm{kg}$ pakan. Pencampuran tepung batang pisang ke dalam pakan dilakukan dengan menambahkan progol $5 \mathrm{gr} / \mathrm{kg}$ pakan yang berfungsi sebagai perekat (coating).

\section{Hasil}

Tingkat kelangsungan hidup (SR) pada penelitian ini menunjukan hasil yang tidak berbeda nyata antar perlakuan (Gambar 1). Nilai SR yang diperoleh berturut-turut yaitu B $(91,30 \%), \quad$ C $(88,40 \%)$ dan A $(81,15 \%)$. 


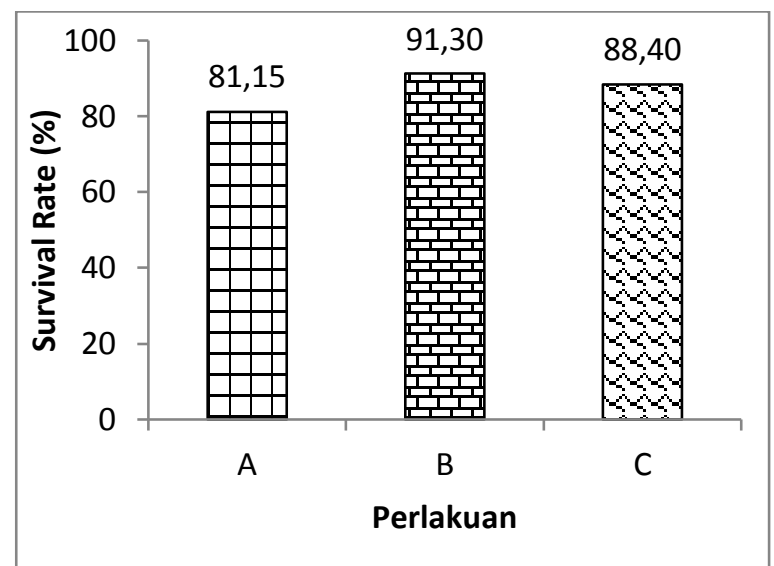

Gambar 1. Survival rate udang vaname selama 30 hari pemeliharaan dengan penambahan tepung batang pisang pada pakan

THC pada penelitian ini menunjukan hasil yang tidak berbeda nyata antar perlakuan (Gambar 2). Nilai THC yang diperoleh berturut-turut yaitu $\mathrm{B}$ $\left(9,18 \times 10^{6} / \mathrm{ml}\right)$, A $\left(6,63 \times 10^{6} / \mathrm{ml}\right)$ dan $\mathrm{C}$ $\left(5,87 \times 10^{6} / \mathrm{ml}\right)$.

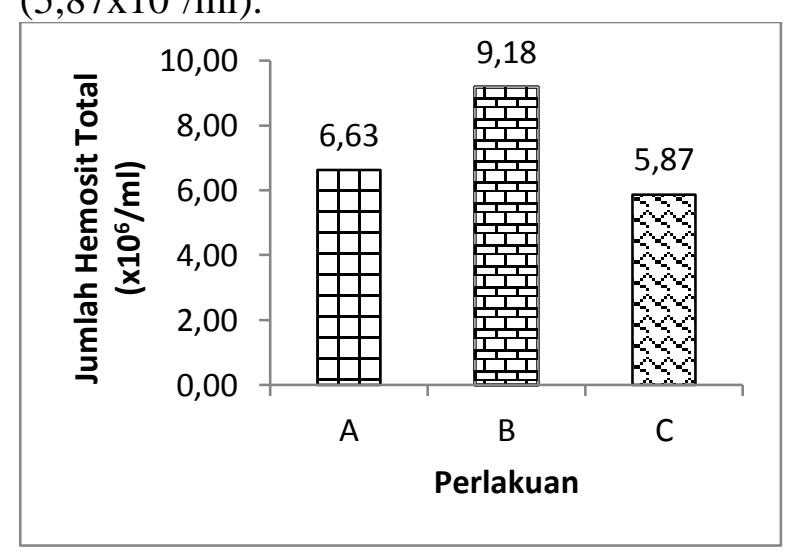

Gambar 2. Jumlah hemosit total udang vaname selama 30 hari pemeliharaan dengan penambahan tepung batang pisang pada pakan

\section{Pembahasan}

Menurut WWF-Indonesia (2014) SR udang vaname yang dibudidaya secara semi intensif di tambak adalah sebesar $81 \%$. Jika dibandingkan maka SR pada penelitian ini masih termasuk dalam SR optimal pada budidaya udang vaname. Salah satu faktor yang mempengaruhi SR adalah padat tebar. Dimana padat tebar yang digunakan pada penelitian ini adalah sebesar 500 ekor $/ \mathrm{m}^{3}$. Padat tebar tersebut merupakan padat tebar budidaya skala intensif (Supriyono dkk, 2016). Faktor lain yaitu kualitas air. Kualitas air yang diamati selama 30 hari pemeliharaan udang vaname ini tersaji pada Tabel 1.

Tabel 1. Data kualitas air selama penelitian

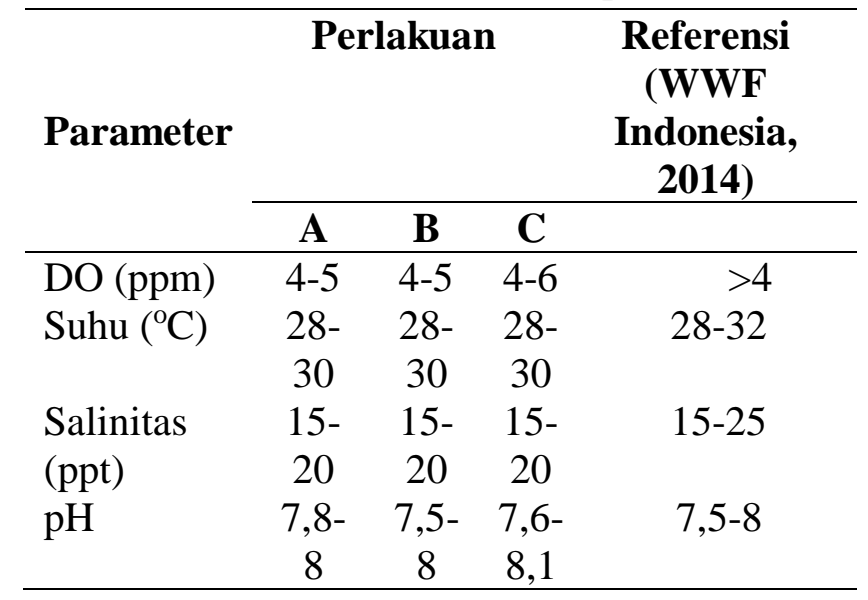

THC pada penelitian ini menunjukan hasil yang lebih tinggi yaitu

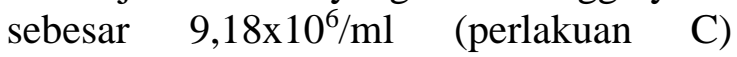
dibandingkan penelitian Fadillah, dkk (2019) yang menghasilkan THC sebesar 7,55×10\% $/ \mathrm{ml}$. Menurut Sahoo et al., (2007), hemosit merupakan salah satu sistem pertahanan pada udang vaname yang bertanggung jawab terhadap fagositosis, nodulasi dan enkapsulasi. Jumlah hemosit yang tinggi menunjukkan tingkat kesehatan udang yang baik. Dengan demikian dapat diduga bahwa penambahan tepung batang pisang pada pakan udang vaname dapat meningkatkan nilai THC. Sehingga sistem imun udang vaname menjadi lebih baik. Hal ini dapat disebabkan oleh kandungan tannin, saponin dan flavonoid yang ada pasa ekstrak batang pisang. Dimana tannin dan flovonoid dapat berfungsi sebagai anti radang. Serta kandungan saponin, antrakuinon dan kuinon berfungsi sebagai antibakteri dan penghilang rasa nyeri (Apriasari dkk, 2013).

\section{Kesimpulan}

Kesimpulan yang didapatkan dari penelitian dengan judul "Peningkatan 
Pertumbuhan dan Kesehatan Udang Vaname (Litopenaeus vannamei) dengan Penambahan Tepung Batang Pisang pada Pakan" tidak menunjukan hasil yang berbeda nyata antar tiap perlakuan. Namum perlakuan B yaitu perlakuan penambahan tepung batang pisang dengan dosis $4 \mathrm{gr} / \mathrm{kg}$ pakan menghasilkan rata-rata bobot dan laju pertumbuhan serta status kesehatan tertinggi diantara perlakuan lain.

\section{Daftar Pustaka}

Antonius. 2014. Efektivitas Suplementasi Tepung Batang Pisang Dan Probiotik Terhadap Kecernaan Hasil Samping Kelapa Sawit Serta Emisi Metana. Tesis. Institut Pertanian Bogor

Apriasari ML, Carabelly AN, Andini GT. 2013. Ekstrak Metanol Batang Pisang Mauli (Musa sp) dosis 125-1000 mg/kg BB Tidak Menimbulkan Efek Toksik pada Hati Mencit (Mus musculus). Jurnal Dentofasial Vol 12 (2): 81-85

Efrianti, R. 2013. Pemberian Ekstrak Batang Pisang Ambon (Musa paradisiaca) pada Media Pemeliharaan untuk Meningkatkan Kelangsungan Hidup Larva Ikan Gurame (Osphonemus gouramy). Skripsi. Institut Pertanian Bogor

Fadillah N, Waspodo S, Azhar F. 2019. Penambahan Ekstrak Daun Mangrove Rhizophora apiculata pada Pakan Udang Vaname (Litopenaeus vannamei) untuk Pencegahan Vibriosis. Journal of Aquaculture Science Vol 4 (2): 91-101

Indraswari, DAP. 2016. Pemberian Ekstrak Batang Pisang Ambon Musa paradisiaca Melalui Pakan untuk Mencegah Penyakit Motile Aeromonad Septicaemia pada Ikan Lele Clarias sp. Skripsi. Institut Pertanian Bogor

Kartika GRA dan Suryaningtyas EW. 2015. Kandidat Probiotik Ramah Lingkungan yang Berasal dari Batang Pisang (Musa paradisiaca) untuk
Peningkatan Produksi Ikan Air Tawar. Senastek. Bali

Lidiawati E. 2014. Efektivitas Perendaman Ikan Lele (Clarias sp) pada Ekstrak Batang Pisang Ambon (Musa paradisiaca) yang Diinfeksi Bakteri Aeromonas hydrophila. Skripsi. Institut Pertanian Bogor

Medistiara, Y. 2017. Produksi Udang Turun Jadi 265.000 ton Tahun Lalu. https://finance.detik.com/beritaekonomi-bisnis/3433995/produksiudang-turun-jadi-265000-ton-tahunlalu. 10 Juli 2017. 8.31WIB

Munadjim. 1983. Teknologi Pengolahan Pisang. Jakarta. PT Gramedia

Priosoeryanto, BP. Huminto H, Wientarsih I, Estuningsih S. 2006. Aktivitas Getah Batang Pohon Pisang dalam Proses Persembahan Luka dan Efek Kosmetiknya pada Hewan. LPPM. Institut Pertanian Bogor

Pusat Data dan Sistem Informasi Pertanian (PDSIP). 2016. Outlook Komoditas Pertanian Sub Sektor Hortikultura. Kementerian Pertanian

Ramadhan A, Nuryati S, Priyoutomo NB, Alimuddin A. 2017. Dietary Ambon Lumut Banana Stem Extract Musa cavendishii var, dwarf Paxton as an Immunostimulant for White Spot Disease Prevention in Pasific White Shrimp Litopenaeus vannamei. Jurnal Akuakultur Indonesia 16 (2): 164-173

Sahoo PK, Pillai BR, Mohanty J, Kumari J, Mohanty S, Mishra BK. 2007. In vivo humoral and cellular reaction, and fate of injected bacteria Aeromonas hydrophila in freshwater prawn Macrobrachium rosenbergii. Fish and Shellfish Immunology 23:327-340

Supriyono, E. Purwanto, E. dan Utomo, N. B. P. 2006. Produksi Tokolan Udang Vanamei (Litopenaeus vannamei) dalam Hapa dengan Padat Penebaran yang Berbeda. Jurnal Akuakultur Indonesia 5(1): 57-64

Utami W, Sarjito, Desrina. 2016. Pengaruh Salinitas Terhadap Efek Infeksi Vibrio 
Jurnal Perikanan (2019) Volume 9. No. 2 : 188-193

DOI : https://doi.org/10.29303/jp.v9i2.169

harveyi pada Udang Vaname (Litopenaeus vannamei). Journal od Aquaculture Management and Technology 5 (1): 82-90

WWF Indonesia. 2014. BMP Budidaya Udang Vaname Tambak Semi Intensif dengan IPAL. Seri Panduan Perikanan Skala Kecil Edisi 1. Jakarta: WWFIndonesia
Zulfa D. 2018. Ekspor udang vaname di luar prediksi. www.aquaculturemai.org/archives/2403 